Die Welt des Islams 


\section{Die Welt des Islams}

Internationale Zeitschrift für die Geschichte des Islams in der Neuzeit

International Journal for the Study of Modern Islam

herausgegeben von/edited by

Rainer Brunner, CNRS, PSL Research University Paris, France, in Verbindung mit/in cooperation with

Constance Arminjon, École Pratique des Hautes Études (EPHE-PSL), France

Jan-Peter Hartung, University of Gottingen, Germany

Christoph Herzog, University of Bamberg, Germany

Michael Kemper, University of Amsterdam, The Netherlands

Johanna Pink, University of Freiburg, Germany

Stefan Reichmuth, University of Bochum, Germany

Serena Tolino, University of Bern, Switzerland

Rezensionen / review editor: Ruth Bartholomä, German Orient Institute Istanbul, Turkey

Volumes published in this journal are listed at brill.com/wdi 


\title{
Die Welt des Islams
}

International Journal for the Study of Modern Islam

\author{
VOLUME 62 (2022)
}

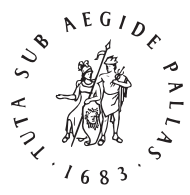

B R I L L

LEIDEN | BOSTON 


\section{Abkürzungen/Abbreviations}

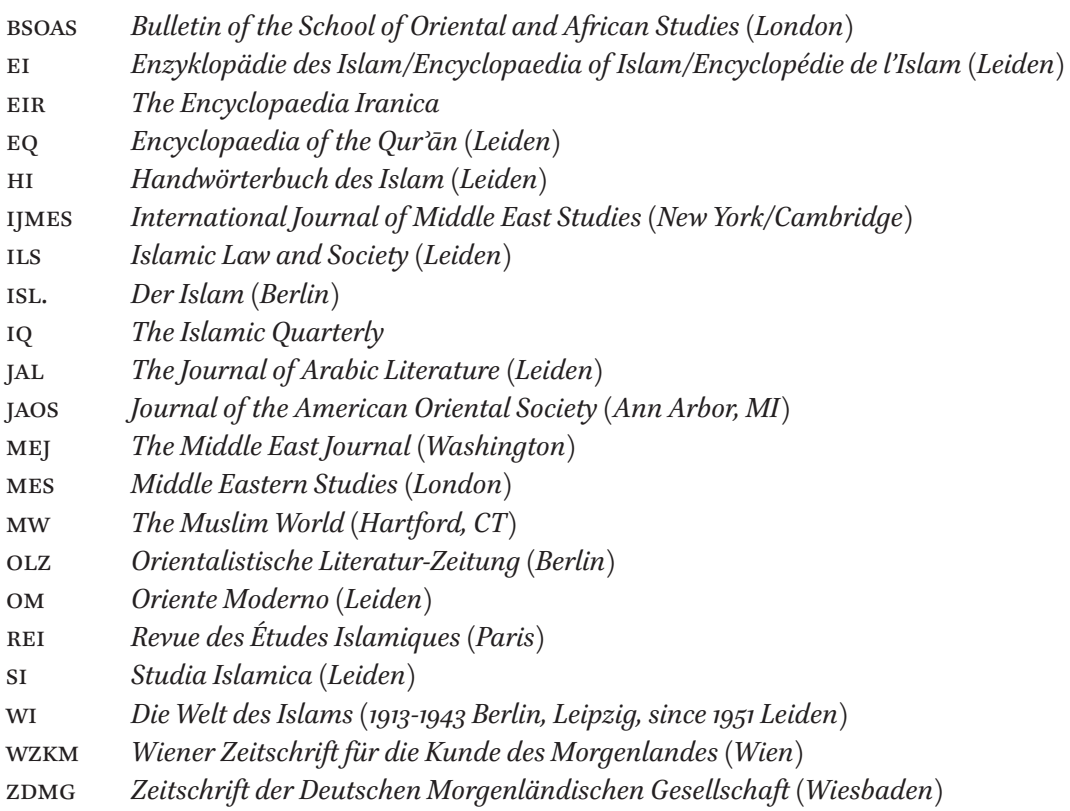

Brill Open Access options can be found at brill.com/openaccess.

Typeface for the Latin, Greek, and Cyrillic scripts: "Brill”. See and download: brill.com/brill-typeface.

ISSN 0043-2539

E-ISSN 1570-0607

Copyright 2021 by Koninklijke Brill Nv, Leiden, The Netherlands.

Koninklijke Brill NV incorporates the imprints Brill, Brill Hes \& De Graaf, Brill Nijhoff, Brill Rodopi,

Brill Sense, Hotei Publishing, mentis Verlag, Verlag Ferdinand Schöningh and Wilhelm Fink Verlag. All rights reserved. No part of this publication may be reproduced, translated, stored in a retrieval system, or transmitted in any form or by any means, electronic, mechanical, photocopying, recording or otherwise, without prior written permission from the publisher. Requests for re-use and/or translations must be addressed to Koninklijke Brill NV via brill.com or copyright.com.

Brill has made all reasonable efforts to trace all rights holders to any copyrighted material used in this work. In cases where these efforts have not been successful the publisher welcomes communications from copyright holders, so that the appropriate acknowledgements can be made in future editions, and to settle other permission matters.

This journal is printed on acid-free paper and produced in a sustainable manner. 